\title{
Laughter, carnival, and religion in ancient Egypt
}

\author{
Andrei Murashko \\ National Research University "Higher School of Economics", Russia \\ amurashcko@yandex.ru
}

\begin{abstract}
The article highlights the problem of interaction of the ancient Egyptian laughter culture with the category of sacred. A person is confronted with the fact that the examples in question can often be phenomena of a different order, and the use of terms such as "carnival" or even "religion," "temple" or "priest" in relation to ancient Egypt requires an additional explanation. We find "funny" images on the walls of tombs and in the temples, where the Egyptians practiced their cult. In the Ramesside period (1292-1069 BC), a huge layer of the culture of laughter penetrated the written tradition in a way that Mikhail Bakhtin called the carnivalization of literature. Incredible events are described in stories and fairy tales in a burlesque, grotesque form, and great gods are exposed as fools. Applying the Bakhtinian paradigm to the material of the Middle and New Kingdom allows to reveal the ambivalent character of the Ancient Egyptian laughter: the Egyptians could joke on the divine and remain deeply religious.
\end{abstract}

Keywords: culture of laughter, sacred, ancient Egypt, carnivalization, Mikhail Bakhtin

\section{Introduction}

The religion of ancient Egypt - a complex phenomenon, the totality of beliefs and practices that existed and changed in the territory of the ancient Egyptian state for more than three thousand years of its history - requires a special research approach. According to Stephen Quirke, while using such common terms as "religion," "king," "priest" or "temple," the researcher is in danger of going blind while regarding the ancient Egyptian realities behind them (Quirke 2015: vi). Therefore it becomes extremely important to understand the boundaries in which the discourse is conducted. In order not to fall into error and not to multiply entities, we try to describe each phenomenon within the framework of the existing field and consider the culture from the inside, through the eyes of its carriers. It is clear that, in the case of dead languages and cultures, this approach encounters certain difficulties.

Nevertheless, the preserved monuments of ancient Egyptian culture make it possible to partially approach their understanding. Moreover, many of the phenomena found in them seem universal, in view of the typological parallels drawn with other, more studied cultures. To describe them, a special language has yet to be developed to meet the requirements of modern 
science. Thus, the term "culture of laughter," introduced by the Russian thinker Mikhail Bakhtin in his work on Rabelais (Bakhtin 2009 [1968]), was used by the scholar and his followers very widely. However, "heute ist man sich allerdings weithin einig, daß es Feste des Saturnalien-typus in Ägypten nicht gegeben hat und daß von irgendeinem rituellen Sitz im Leben dieser Literatur nicht gut die Rede sein kann [today, everyone agrees that, in Egypt, there were no holidays like the Saturnalia and that there can be no talk of any ritual place in the life of this literature]," writes Jan Assman, speaking about literary works discovering something in common with Bakhtin's “carnivalization" (Assman 1993: 41).

The basis for our approach is provided by a large body of literature on Ancient Egyptian humour and the culture of laughter. The last term refers to a historical-anthropological theory developed in Rabelais and His World, based on observations of popular culture in the Renaissance. The culture of popular laughter combines two literary ideas devised by Bakhtin in the same work: the idea of carnivalesque debauchery and grotesque body. Bakhtin analysed François Rabelais' book Gargantua and Pantagruel and created his theory of "grotesque realism" and carnival - an annual festival during which all social norms were subverted. Both concepts, however, were accepted and applied far outside Renaissance and pure literary theory by modern scholars.

According to J. Assman (Assman 1999), an unprecedented event for ancient Egyptian literature occurs in the era of the Ramessides (1292-1069 BC), when a distinction between "classical" and "modern" literature appears for the first time. Some part of the oral tradition was textualized, while retaining its entertainment function. This way, a huge range of folk culture penetrated the literature of the New Kingdom, which was reflected in the content, language, and genre originality of many pieces. In essence, this process represents what Bakhtin called "carnivalization."

\section{Comic imagery}

The laughter culture in ancient Egypt began to attract interest from the 70s of the last century. The achievements of many scholars were summarized in the most famous work of Patrick F. Houlihan, Wit and Humour in Ancient Egypt (Houlihan 2001). In it, the author identifies comic motifs in the literature and visual heritage of ancient Egypt, which can be divided into following groups: a) comic scenes of everyday life, b) festival images, c) funny pets and servants, d) playing with canon, e) animals performing human activities, e) images of strangers, and g) hyperbolic images in scenes of a sexual nature. In addition to the tomb images, the main sources of the ancient Egyptian humour are the papyri, as well as the painters' "sketches" made on pieces of papyrus or on ostraca, which they often left right on the tomb floor, where "fair" images were on the walls. The greatest number of such finds are related to Deir el-Medina, the settlement from which the brilliant sample of the New Kingdom literature called "The Contendings of Horus and Seth" comes from.

The earliest examples of Egyptian humour we find where they would seem to have no place. The famous "satirical" papyri (the Cairo papyrus JE 31199, the London papyrus BM EA 10016, and, the most famous of them, the Turin satirical-erotic papyrus CGT 55001) are the late successors of those images that arose once in the tombs of the nobles of the Old Kingdom. The observance of the funeral cult was supposed to provide eternal life to the master of the tomb, but cheerful Egyptians, apparently, considered it permissible to "joke" over the earthly path they had overcome.

Many of the tomb images of this kind look like ancient Egyptian "comics" (from the English comic, which means "funny") and depict scenes from those distant times. These are a police baboon who grabbed a thief on the market by the foot (Houlihan 2001: 18), the scolding 
of shepherds moving a herd across the river (Houlihan 2001: 29), and many, many more. In addition, we find examples of the laughter culture in the centers of the Egyptian cult: in the Temple of Mut in Karnak (the so-called "porch of drunkenness"), in the Luxor Temple (taking a Syrian fortress with a fugitive attacked by a bear (Houlihan 2001: 59)), in the funeral temple of Hatshepsut (the "overweight" wife of a foreign ruler (Houlihan 2001: 57)), and in the Ramesseum (drowning prince of Aleppo (Houlihan 2001: 58)).

Among the numerous drawings, some are filled with certain social critics and even with anti-religious content. Here, jackal priests worship the mouse as a god (Houlihan 2001: 97), and there, the bull leads the cat to the donkey for trial (Houlihan 2001: 70). A lion, seen as a caricature of Ramesses III, plays senet with an antelope. In a pair of a quartet similar to that from the fable of Ivan Krylov, consisting of a donkey, a lion, a crocodile, and a monkey, one can find the same image with female musicians (Petrovsky \& Belov 1973: 295). Such pictures of the inverted world are well known from the Russian lubok.

There is a reason to believe that the "indecent" rock graffito not far from the Temple of Hatshepsut (Houlihan 2001: 129) is a depiction of the queen (on the woman's head, one can distinguish the uraeus, a stylized image of the cobra goddess Wadjet which belongs to the royal dress of the pharaohs). If it is so, then we deal with a satire against the queen with her favourite Senenmut. Similarly, a small sculpture from Amarna with monkeys keen on grooming could express folk sentiments about the ruling family. Of the same nature is the New Kingdom letter, in which Ramesses II is called "the old general" (Silverman 2001: 128).

\section{Humour in literary works}

Since ancient times, a special stratum of the population was formed in Egypt, consisting of scribes, the priesthood, and the ruling class, who felt the need for calculations and business correspondence. The privileged status of the scribe is the subject of the educational text "The Satire of the Trades" (pSallier II), which was popular in the Ramesside period. In it, the author ridiculed the severity of the professions of a sculptor, carpenter, potter, fisherman, landowner, messenger, etc., as opposed to the profession of a scribe. This Egyptian elite was very educated and had a peculiar sense of humour. Rough folk speech seemed ridiculous to them. A typical example is the correspondence of the 13th century, built entirely according to the "inverted" canon. The postscript can be read: "Come that I may see you. See we will have a bad time" (Houlihan 2001: 2-3).

The verb "to laugh" (Egyptian: $s b T$ ) and its derivatives are found in the works of the most different genres, including religious, monumental, literary, and non-literary texts. The Pyramid Texts tell us that laughter and shouting accompany the ascension of the King to heaven (1149) and that, as sorrow subsides, laughter begins (1989) (Silverman 2001: 128). According to one (rather late) version, Atum creates gods with laughter (Tomashevich 1999: 45), as opposed to "imperfect" people (Egyptian: $r m T)$, created from his tears $(r m w t)$. Thus, wordplay and humour became an integral part of mythology. In the "Book of the Heavenly Cow," the goddess Sekhmet, who drank beer, which she mistook for the blood of humanity destroyed by her, was easily deceived by her father Ra.

We find a lot of laughter in ancient Egyptian tales. In "The Shipwrecked Sailor," the immortal serpent, the master of the island, laughs at the unfortunate sailor who does not know about his own insignificance ("He laughed at me for that I said, and because of that he had in his heart" (Maspero 2002: 87)). The tale is filled with puns (Rendsburg 2000), which could also have an attractive effect. The narrative "frame" of the text is saturated with bitter irony, in which, after an extraordinary story, the final remark sounds: "Do not be malicious, my friend. Who gives water to a goose on the morning of the day it is to be killed?" (Maspero 2002: 88). 
In the famous "Story of Sinuhe," the ruler of Upper Retjenu, after listening to a hymn of praise to King Senusret, tells the guest: "Verily, Egypt is happy in that she knows the vigour of her prince! As to thee, since thou art here, stay with me and I will do well for thee" (Maspero 2002: 65). It might seem comical that Sinuhe kills a strong man with his own battle-axe (compare 1 Kings 17:51). An incredibly subtle play arises when the fugitive returns to his homeland, and in the "dialogue of the deaf" that he leads with the pharaoh, the impression is created that they are talking about different things.

The comic can be found in the tales of the Westcar Papyrus. In addition to the general situation of the courtly amusement of the king, the image of the pharaoh Sneferu, endowed with satirical features, is striking. Indeed, the ruler misinterprets, in an erotic sense, the recommendation made to him to go on a river walk in the company of beautiful maidens. The imposition of one part of the lake on the other - the prototype of the sea divided by Moses also seems to be a hyperbole aimed at achieving the comic because its purpose is to get a golden fish-earring of one of the women. The ridiculous names of some characters could also cause laughter (Chegodaev 2016), especially since they were accompanied by unprecedented miracles. Nevertheless, in the Middle Kingdom, there are no completely humorous tales: here we see only separate sparks of humour.

In the Ramesside period, such interesting works as "The Doomed Prince," "The Taking of Joppa," and "The Quarrel of Apophis and Seqenenre" appear (Di Biase-Dyson 2013: 231-233). Apophis's demand to drive off the hippos that prevent him from sleeping seems absurd because Thebes, where Seqenenre was, and his residence in Avaris were separated by a distance of more than $650 \mathrm{~km}$. Close to these texts is "The Journey of Wenamun." In response to the demand to load the timber onto the ship, the Prince of Byblos promises to the Egyptian nobleman to show the grave of the envoys of Khamoîs - his predecessors who died in a foreign land - and says to his intimate: "Take him to see their tomb in which they are laid" (Maspero 2002: 179).

If desired, this corpus of literature could be continued with such later pieces as "The Adventure of Satni-Khamoîs with the Mummies" (in the demotic tale, the deceased Nenoferkephtah causes the hero to sink into the ground with a playing-board of senet) or the tale about unlucky thieves, one of whom lost his head, and so on. The number of copies and a strong oral tradition allow us to assume that these stories were widely known. However, the pinnacle of ancient Egyptian humorous literature, according to many scholars, is "The Contendings of Horus and Seth."

\section{Divine mockery in "The Contendings of Horus and Seth"}

The papyrus Chester Beatty I was exemplarily published by a prominent Egyptologist, the Englishman Alan Gardiner (Gardiner 1931). It dates from the 20th Dynasty and refers to the reign of pharaoh Ramesses $\mathrm{V}$. The manuscript comes from the personal collection of the scribe Kenherkhepeshef (Deir el-Medina) and was seemingly intended exclusively for the amusement of its owners. The papyrus contains the story of the lawsuit of Horus and Seth, as well as a number of poetic works of love lyrics. The writing place for 16 hieratic pages $55-\mathrm{cm}$ wide, apparently, was Thebes. The 5.02-meter papyrus was published by Oxford University Press in 1931 and is currently located in the Chester Beatty Library in Dublin.

According to Gardiner, if "The Tale of the Two Brothers" and "The Blinding of Truth" were moralistic folktales in the manner of Hans Andersen, then "The Contendings of Horus and Seth" is "mythology up-to-date and somewhat in the spirit of Offenbach" (Gardiner 1931: 9). He also compares the excesses that occurred with the heroes of the tale with the behavior of the Greek gods in Homer's Odyssey (Gardiner 1931: 10). From the very beginning of the 
dispute, it is clear that, in fairness, the throne belongs to Horus but the supreme god wants to give it to Seth. Horus has bad breath, the gods vomit on him, they speak in a completely nondivine language. In a word, they seem to be turning into tricksters. From other mythologies, we know about the tricks of Zeus or Indra but the Egyptian gods were traditionally endowed with greater seriousness.

An early version of one of the key episodes of the "Contendings," dating back to the late Middle Kingdom (12th Dynasty), was discovered near the village of El Lahun by archaeologist Flinders Petrie in 1889. A hieratic fragment on a piece of papyrus only about 14-cm long concerned the most delicate moment in the confrontation of two gods: the so-called "homosexual episode." One can imagine the excitement of scientists who first encountered such a text. "Your buttocks are beautiful two times," - Seth tells the young nephew. The talented philologist Francis Llewellyn Griffith decided to publish the fragment, only after having clothed immodest passages in pious Latin (Griffith 1989: 4).

Obviously, the basis of the tale is mythological plots. Most scholars agree with its reading as a parody of a myth and even a satire of legal proceedings (Livshits 1979: 258-259). The gods are endowed with human flaws, their characters are not described in verbal descriptions; they are shown in their deeds and actions. The eccentric behaviour and statements of the heroes violate existing norms, they are accompanied by an atmosphere of scandal, the motive of insanity and related dreams, sleep, etc. One can find interesting discussions about the quarrel of Horus and Seth by Isaak Livshits, who paraphrased E. F. Wente: "In the Ramesside period, a certain duality manifested itself in relation to religion. On the one hand, the gods were treated with rude humour, on the other hand, reverence and respect for them remained. People could have fun about such episodes and still be religious" (Livshits 1979: 258).

Of great interest is the article by Robert A. Oden Jr. "“The Contendings of Horus and Seth' (Chester Beatty Papyrus No. 1): A Structural Interpretation" (Oden 1979). In this work, the author pays tribute to C. Levi-Strauss and tries to apply his methods to the material of the ancient Egyptian tale. Oden names three approaches to explaining a fairy tale: 1) entertainment function (Gardiner, Griffiths, Posener); 2) mytho-ritualistic explanation; and 3) assumption that the myth reflects the history of the past (K. Sethe and others). The scholar himself prefers structuralism to a historical or functionalist approach. It is true that the tendency to explain reality by means of binary oppositions is rarely presented anywhere like in this myth. Using the semantic square, the researcher creates a scheme of four genealogical relationships (SethHorus, Seth-Isis, Osiris-Isis, and Osiris-Horus) and concludes that only after articulating the fourth component can the myth reach its final. At the same time, according to Oden, nothing happened at the plot level that would demonstrate that Horus is worthy of his father's inheritance. Moreover, the myth ends with a significant inversion: Horus becomes the earthly ruler and the chthonic god Seth, hostile to all gods from the semantic square, rises to the sky and becomes the son of Ra-Horakhty. From the point of view of the Egyptian religion, young Horus lacks neither experience nor power; Seth has both. In the "Contendings," the gods collide in a series of seemingly intractable conflicts, instead of resolving them completely.

The punch line of contemporary studies in ancient Egyptian laughter is the focus on the language of written monuments and wordplay which can be found in them as another source of the comic. In this sense, "The Contendings of Horus and Seth" is the highest manifestation of a stunning possession of this technique, and the written text is designed as if it consisted entirely of spelling errors. The result is "almost a gag - an amazing self-parody of the story itself" (Chegodaev 2016: 355). The brilliant philologist Antonio Loprieno (Loprieno 2000) reviews Egyptian texts of various genres, showing interesting examples of wordplay and explaining how familiar puns worked for Egyptians. In this case, the researcher emphasizes the great importance of such a play in the analysis of hieroglyphic monuments. 
From the library of the same ancient Egyptian scribe as the "Contendings" comes a very interesting monument - the Ancient Egyptian dream manual (papyrus Chester Beatty III), written in the time of Ramesses II. Often, the explanations are rather vague and similar dreams often have different meanings; in many cases, the interpretation was the opposite of what the dream depicted. The papyrus is replete with puns, which often serves the purpose of interpretation. Alliteration, antanaclasis (repetition of the word in the changed meaning), homeoteleuton (repetition of the final part of the word), onomatopoeia (phonetic imitation), paronomasia (similarity in sound), polysemy, translexical and visual puns formed the basis of the typology that the scholars Scott Noegel and Kasia Szpakowska (Noegel \& Szpakowska 2007) consider applicable to the Ramesside dream manual in particular and to all ancient Egyptian literature in general, as well as to wordplay in a wider Middle Eastern context.

Wordplay is the same characteristic element of carnival culture as masks or popular folly. In one of the episodes of the "Contendings," Isis, turning into a beautiful woman, tells Seth, who is attracted to her, the story of the son of a shepherd into whose house a stranger bursts in, threatening to beat him and take away his father's cattle. The indignant Seth exclaims: "Shall the cattle be given to the foreigner, while the son of the goodman is yet alive?" (Gardiner 1931: 18). The fact is that, in the Egyptian language, the words $i A w t$ "cattle" and $i A w t$ "[royal] office" differ in writing only by determinatives. Thus, cunning Isis forces Seth to admit the injustice of his own claims to the throne of Egypt. An additional comic effect is achieved when Seth's constant epithet aA pHty "rolls over" and is written out not through the two heads of the leopard

(hieroglyph F9

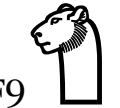

) but through its back (F22 NJ).

It is clear what high demands such manuscripts require from the reader, who should not only be fluent in the Egyptian language, but also possess (at least to a certain extent) a sense of humour. Such mocking intellectuals apparently were the ancient Egyptian scribes in general and the inhabitants of Deir el-Medina in particular, the "middle class," in the case of necropolis workers, who also led an isolated existence in a community with a strict hierarchy, functioning according to its own laws (Bogoslovsky 1983). The closest analogy from the theory of Bakhtin's carnival for such a group is represented by medieval monks who, tired of church dogmas, created joca monacorum in their cells just for fun.

From the inhabitants of the village of the pharaoh's workers we learn the ancient Egyptian "joke" about a one-eyed wife (Houlihan 2001: 1-2); they also create a comic tomb scene with masters, when one of them taps a hammer on the leg of his comrade (Houlihan 2001: 50), as well as a huge number of "popular" images of an inverted world (cats serving mice and grazing geese, or jackals dancing with goats, etc.) and other humorous sketches. When the builders were not busy constructing the royal tombs, they devoted their leisure time to working on these drawings - for training or just for fun (Houlihan 2001: 62).

It is from this environment that the papyrus Chester Beatty I comes from. Researchers have long noticed "folk humour" in a fairy tale recorded on his recto (Livshits 1979: 258). The myth of Horus and Seth, known from many other sources, under the pen of a refined scribe elite, was carnivalized and began to serve for private amusement. Thus arose, in the Bakhtinian language, the ancient Egyptian parodia sacra ${ }^{1}$.

Numerous stelae, graffiti, and other remnants of non-literary material written in different handwriting indicate that literacy in Deir el-Medina was possessed not only by those who held the honorary title of scribe ${ }^{2}$, but also by many foremen, draftsmen, stone-diggers, carpenters,

${ }^{1}$ Bakhtin himself, apparently, did not quite accurately use this term (Newman 2013: 168-169).

2 The word $s S$, "scribe," in Deir el-Medina, could have meant anyone who could write, just like the word $H m w$, "carpenter," could simply indicate the ability to do the job of a carpenter (Pestman 1982: 171). In addition, it is not always clear whether we are talking about "scribes" or "painters" (Bogoslovsky, 1983: 11). 
and also their wives (Lesko 2001: 297). This was also expressed in the special spiritual and intellectual needs of the masters (among which humour did not take the last place, including, possibly, the political context), which gradually formed a special, in modern terms "nonconformist" cultural substrate. It is not surprising that, in the 29th year of the rule of Ramesses III, for the first time in history, a strike of workers who had not received a salary for a month took place there.

\section{Was it a "carnival"?}

The answer to the question of presence or absence in Egyptian literature, religion, and culture in general of such a phenomenon as carnivalization depends largely on what is considered carnival. Using the Bakhtinian formula, we will assume that the carnival is primarily what gives us a picture of an inverted out-of-carnival world, the "world inside out" (Bakhtin 2009 [1968]: 11). Therefore, for example, the war of cats and mice, in which the weaker win, is undoubtedly a carnival. Images of the same "funny" pets, dwarfs, etc. on the walls of the tombs, although probably belonging to the so-called "laughter culture," are, in fact, not carnivalesque (unless we consider the fact of the penetration of such images into the "frame" of tomb painting as "turning inside out").

Camilla Di Biase-Dyson offers an interesting view of the problem of the carnival. The researcher considers the history of Apophis and Seqenenre as one of the examples of carnivalization. However, she notes that the text recorded on papyrus Sallier I was the scribe Pentauret's school exercise, and therefore refers to the normative culture rather than the carnival, as it may seem at first glance on its content. She suggests considering this narrative, along with "The Taking of Joppa," as a model of social criticism (or social commentary), which, ridiculing high-ranking persons and thus remaining in the framework of the Bakhtin's carnival, could be produced not only by the lower class, but also by the educated elite (Di Biase-Dyson 2013: 232, 255).

The finale of "The Contendings of Horus and Seth" is indicative. As it was mentioned, at the end of the story, the heavenly Horus becomes the earthly ruler and the chthonic Seth ascends to heaven. There is undoubtedly something from the carnival in this final inversion. Perhaps the rendering of such "honour" to the murderer of Osiris is due to the attitude towards the god transformed by the Ramessides (he was directly connected with the King's authority) or to his positive role as the defender of the sun barque in the daily journey of the god Ra (Seth himself reminds us of this fact in the fairy tale). It may be, however, that Seth is placed in such a high place, firstly, for the sake of laughter, and, secondly, as a sign of bitterness against official ideology. In the era of Romanticism, something similar can be found in the love that J. G. Byron had for Cain and Satan. Thus, carnivalization (precisely in the Bakhtinian sense) is manifested at all levels of the ancient Egyptian text: in the ideological-semantic, subjective, and language planes.

Even if there is an assimilation of the heroes of the fairy tale with Ramesses $\mathrm{V}$ and Ramesses VI, an uncle and a nephew, "The Contendings of Horus and Seth" was still not a satire in its generally accepted meaning of ridicule, which deals with allegory (what is depicted is not what is implied). It is not without reason that Bakhtin reacted to satire negatively and considered its strengthening in the post-carnival era as a symptom of the decline of ambivalent popular laughter (Kozintsev 2010: 190). A. Loprieno believes that the parodic or sarcastic character of the "Contendings," which scholars usually associate with its function as political satire, is nothing more than a "projection of material otherwise known from referential contexts into a truly literary, i.e., human dimension, in which ideology is continuously challenged by individual mimesis" (Loprieno 1996: 50). 
The most sacred was ridiculed and something similar was put in its place, precisely because the genuine needed concealment and protection. Olga Freidenberg brilliantly showed that, once, in effective parodies, the gods played the main role, that the mockery appealed to them, and that its role was sacred (Freidenberg 2006: 239). The solution could be the phenomenon of carnivalization discovered by Bakhtin: penetrating the myth, folk religion, and humour could give to Horus the features of Ramesses, although, of course, god himself was meant. Of great interest is the phenomenon of refolklorization arising against this background - the return of the myth of Horus and Seth to the fertile soil of folklore.

As Bakhtin rightly observes: "In the folklore of primitive peoples, coupled with the cults which were serious in tone and organization were other, comic cults which laughed and scoffed at the deity ('ritual laughter'); coupled with serious myths were comic and abusive ones; coupled with heroes were their parodies and doublets" (Bakhtin 2009 [1968]: 6). The meaning of these stories is clarified by A. Kozintsev: the heroes of trickster myths inhabit " "third world of reference,' which, in effect, is a world of nonreference" (Kozintsev 2010: 139). And therefore: "Jokes 'about Chapaev' are not about Chapaev, just as jokes 'about Stalin' are not about Stalin" (Kozintsev 2010: 140). The same can be said about the comic in the ancient Egyptian tale.

Thus, before us appear not the mighty gods Horus and Seth but the "comic Horus" and the "comic Seth," their laughable doubles. However, the situation here is somewhat more complicated, since the monument preserved on papyrus Chester Beatty I is not a piece of folklore but truly "literature," the work of the sophisticated humour of Egyptian scribes, which means the "tricksterization" of the deities in it is the result of refolklorization and deliberate decline by returning to the folk roots of the myth.

\section{Conclusion}

Though the problem of Ancient Egyptian laughter has been examined by leading authorities like Assman and Loprieno, it still seems to offer lots of room for debate. Upon closer examination, it turns out that most of the material that formed the basis of Houlihan's book refers to phenomena of various orders, and what seems to be funny to the modern researcher was not always the same for the Egyptian. On the contrary, "funny" monuments are often related to the category of the sacred, being integral parts of religious practices, and have an important cultural significance, other than comic. According to the successful expression of Olga Tomashevich, which compares laughter with smell, "we can probably feel its former presence only at the level of intuition" (Tomashevich 1999: 44).

Take, for example, the mentioned "comics" and images on the walls. Since the tomb was perceived as a door to another world, it was extremely important for the Egyptians to recreate their world in all its details on its walls, be it the abuse of the Egyptian "cowboys" or the incident on the market (see above). Such Egyptian realism was justified by the belief in the afterlife that repeats the earthly existence. The same can be said of the triumph and ridicule of the victor over the vanquished, presented in the Ramesseum. Talking about the "culture of popular laughter" in ancient Egypt is also very difficult due to the poor preservation and heterogeneity of the finds.

It is nevertheless worth noting that the distinctly comic "Contendings of Horus and Seth" is not the only example of frivolous treatment of the gods. A myth comes to us from the same region in which the insidious Isis sends a poisonous snake to the god Ra to find out his hidden name, as well as the lesser-known myth of Horus and Nemti. The latter has survived only fragmentarily but it is clear from the text that Horus is also involved in the poisoning of Nemti. Listing the host of his names in a series of traditional epithets, he also mentions names which 
seem "unflattering" for the deity: "a quiver full of arrows" and "a pot full of unrest" (Borghouts 1994: 123). But it is impossible to say with certainty whether such things should have caused laughter.

The main advantage of Bakhtin's theory is that he discovered the carnival as a necessary element of the world order which ensures its normal functioning. Not always carnival means funny, and funny does not always mean carnival. However, a certain need for transgression can be considered universal for human communities; therefore, it is not surprising that even archaic cultures, such as ancient Egypt, obeyed the same laws as the crowd on the medieval square, even if the Egyptian holidays were not the same as the Medieval or Renaissance ones. "The abolition or inversion of hierarchy, all sorts of 'coarse bodily contact,' of jocular beatings in particular, 'ambivalent praise-abuse' - all that Bakhtin called 'carnivalization' - is paralleled by the Australian festival, and if one excludes verbal patterns, then by the playful behaviour of nonhuman primates as well" (Kozintsev 2010: 186). The carnival mechanism consists in creating a second world in which it is possible to laugh at the gods or the doublets replacing them without losing the connection with the real world, to which one has to return.

Returning to the problem of translation, the elements of the fairy tale, to which the notion "carnival" can be applied, do not belong to the original myth: they could be drawn by the author of the "Contendings" from an inexhaustible source of popular laughter culture or simply be a "thing-in-itself," given that we know almost everything about the unique and limited use of this monument. Thus, "The Contendings of Horus and Seth" is not just a trickster myth but somehow the next step. Perhaps Egyptian literature and culture as a whole were better developed than is commonly believed if we find in them phenomena similar to those which took place in Europe many centuries later, or these processes are to be considered eternal and universal.

Nevertheless, using the Bakhtinian paradigm or similar "frames" of other scientists which seem to be suitable for explaining various ancient phenomena, one must be very careful. It is possible to see "comic" and even "carnivalesque" in other pieces of written culture or imagery of ancient Egypt but such a consideration requires a systematic approach, which still needs to be developed.

\section{References}

Assmann, J. (1993). 'Literatur und Karneval im Alten Ägypten', in Döpp, S. (ed.), Karnevaleske Phöänomene in antiken und nachantiken Kulturen und Literaturen, Bochumer Altertumswissenschaftliches Colloquium Bd.13 (Stätten und Formen der Kommunikation im Altertum I). Trier: Wissenschaftlicher Verlag Trier, pp. 31-57.

Assmann, J. (1999). 'Cultural and Literary Texts', in Moers G. (ed.), Definitely: Egyptian literature. Proceedings of the Symposion "Ancient Egyptian Literature - History and Forms”, Los Angeles, March 24-26, 1995 (Lingua Aegyptia: Studia Monographica 2). Göttingen: Peust \& Gutschmidt Verlag GbR, pp. 1-15.

Bakhtin, M. (2009 [1968]). Rabelais and His World. Bloomington: Indiana University Press.

Bogoslovsky, E. S. (1983). Drevneegipetskie mastera. Po materialam iz Der èl'-Medina [Ancient Egyptian Masters. Based on Materials from Deir El-Medina]. Moscow: Nauka.

Borghouts, J. F. (1994). 'Magical Practices among the Villagers', in Lesko, H. L. (ed.), Pharaoh's Workers: The Villagers of Deir El-Medina. Ithaca: Cornell University Press, pp. 119-130.

Chegodaev, M. A. (2016). "Chto èto, Dzhedi?" ["What does it mean, Djedy?"], in Chegodaev, M. A. \& Lavrent'eva, N. V. (eds.), Aegyptiaca Rossica (Vypusk 4). Moscow: Russkiı̆ fond sodeřstviia obrazovaniîu i nauke, pp. 347-367. 
Di Biase-Dyson, C. (2013). Foreigners and Egyptians in the Late Egyptian Stories: Linguistic, Literary and Historical Perspectives. Leiden, Boston: Brill Academic Publishers.

Freidenberg, O. M. (2006). 'Ideia parodii (nabrosok k rabote)' ['The idea of parody (sketch for a work)']. Veche: al'manakh russkou filosofii i kul'tury, 17. Saint Petersburg: Izdatel'stvo Sankt-Peterburgskogo universiteta, pp. 228-240.

Gardiner, A. H. (1931). The Library of A. Chester Beatty. The Chester Beatty Papyri, No. I. London: Oxford University Press.

Griffith, F. Ll. (ed.) (1898). Hieratic Papyri from Kahun and Gurob (Principally of the Middle Kingdom). Vol. 1. London: Bernard Quaritch.

Houlihan, P. F. (2001). Wit \& Humour in Ancient Egypt. London: The Rubicon Press.

Kozintsev, A. (2010). The Mirror of Laughter. New Brunswick, New Jersey: Transaction Publishers.

Lesko, H. L. (2001). 'Literacy', in Redford, D. B. (ed.), The Oxford Encyclopedia of Ancient Egypt (Vol. 2). New York: Oxford University Press, pp. 297-299.

Livshits, I. G. et al. (eds.) (1979). Skazki i povesti Drevnego Egipta [Tales and Stories of Ancient Egypt]. Leningrad: Nauka.

Loprieno, A. (1996). Ancient Egyptian Literature: History and Forms. Leiden; New York: E. J. Brill.

Loprieno, A. (2000). 'Puns and Wordplay in Ancient Egyptian' in Noegel, S. B. (ed.), Puns and Pundits: Word Play in the Hebrew Bible and Ancient Near Eastern Literature. Bethesda, MD: CDL Press, pp. 3-20.

Maspero, G. (2002). Popular Stories of Ancient Egypt. Santa Barbara, Calif.: ABC-CLIO.

Newman, B. (2013). Medieval Crossover: Reading the Secular against the Sacred. Notre Dame, IN: University of Notre Dame Press.

Noegel, S. B. \& Szpakowska, K. (2007). "Word Play”, in the Ramesside Dream Manual'. Studien zur altägyptischen Kultur 35, pp. 193-212.

Oden, R. A., Jr. (1979). “"The Contendings of Horus and Seth” (Chester Beatty Papyrus No. 1): A Structural Interpretation'. History of Religions 18 (4), pp. 352-369.

Pestman, P. W. (1982). 'Who Were The Owners, In The "Community Of Workmen", Of The Chester Beatty Papyri', in Demarée, R. J. \& Janssen, J. J. (eds.), Gleanings from Deir ElMedina. Leiden: Nederlands Instituut voor het Nabije Oosten te Leiden, pp. 155-172.

Petrovsky, N. S. \& Belov, A. M. (1973). Strana Bol'shogo Khapi [The Land of The Big Hapi]. Leningrad: Detskaia literatura.

Quirke, S. (2015). Exploring Religion in Ancient Egypt. The Atrium, Southern Gate, Chichester, West Sussex, UK; Malden, MA: John Wiley \& Sons, Ltd.

Rendsburg, G. A. (2000). 'Literary Devices in the Story of the Shipwrecked Sailor'. Journal of the American Oriental Society 120 (1), pp. 13-23.

Silverman, D. P. (2001). 'Humor and Satire', in Redford, D. B. (ed.), The Oxford Encyclopedia of Ancient Egypt (Vol. 2). New York: Oxford University Press, pp. 127-130.

Tomashevich, O. V. (1999). 'Papirus Chester-Bitti I: smekh i styd v drevnem Egipte' ['Papyrus Chester Beatty I: Laughter and Shame in Ancient Egypt'], in Logunov, A. P. et al. (eds.) Razvitie Tsivilizatsii i Novy̌ Svet: Pervye Knorozovskie chteniia: Materialy nauchnoŭ konferentsii 20-21 oktiabria 1999 g. Moscow: RGGU, pp. 43-45. 